$<$ 原 著 $>$

肝予備能検查法としてのガラクトース負荷試験の実験的検討

一再生肝のガラクトース代謝についてー

\begin{tabular}{|c|c|c|c|c|}
\hline 竹崎 & 英一* & 中西 & 敏夫 & 渡辺 恭行 \\
\hline$川$ & 広夫 & 吉川 & 正哉 & 松浦寿二郎 \\
\hline 竹野 & 弘 & 川上 & 広育 & 梶山 梧朗** \\
\hline
\end{tabular}

要 旨：部分肝切除後, 経日的に ICG Rmax とガラクトース負荷試験を施行し, ICG Rmax が 部分肝切除 1 日後に最小値を示し，以後徐々に回復するのに反し，ガラクトース負荷試験の血 中ガラクトース値半減期は部分肝切除 3 日後まで次第に延長し，以後徐々に回復することを認 めた。これは，肝重量が必ずしも肝の functional reserve cell massを反映するものではない ことを示唆させる実験結果であると考えられた，しかし，部分肝切除後の残存肝は再生肝とい 5代謝的に特異な状態にあることが考兄られ，ガラクトース代謝に拉よぼす再生肝の代謝状態 の影響を考慮する必要を認めた. 部分肝切除後, ガラクトースの代謝系のなかで glucose, 乳酸, glucose-6-phosphatase およびインスリンを選び, 経日的に 7 日間測定し検討した結果, 再生肝


められ，血中インスリンは血糖の変動に応して反応することにより，ガラクトースの肝での取 り込みには関与していないことが示唆された。

索引用語：肝予備能試験 ガラクトース負荷試験再生肝䓋ラクトース代謝 glucose-6-phosphatase

\section{緒 言}

著者らは, 臨床的に肝予備能検查としての ICG Rmax とガラクトース負荷試験の成績間に解離症例 が少なからす存在することに注目し1，ラットを用い て部分肝切除後, 経日的に ICG Rmax とガラクトース 負荷試験を施行し, ICG Rmax は残存肝重量已密接に 平行して変動するが，ガラクトース負荷試験は残存肝 重量とは全く異なった変動を示すことを報告した2).

同様に, Yildirim らは3'部分肝切除後 3 日目まで肝 のガラクトース除去能を測定し，ガラクトース除去能 が 3 日後亲で次第に低下するが，部分肝切除 6 時間啳 に一時的にガラクトース除去能が改善することを報告 し，これを再生肝の代謝状態の特徵と考え，更に，ガ ラクトースの代謝される過程で律速酵素を主とした 酵妻の検討が必要であることを示唆した。

以上のことから，著者らあ部分肝切除後の再生肝に

“広島大学医学部中央検查部

**広島大学医学部第 1 内科

〈受付日59年 2 月 6 日 $>$
は，再生肝に特異的な代謝状態が存在することを考虑 乙, 又, 肝のガラクトース除去能には血中インスリン の濃度が関与するといら報告すあり4), 部分肝切除後, 血糖, 血中乳酸, 血中インスリンおよび肝組織 glucose6-phosphatase 活性を測定し再生肝のガラクトース代 謝について検討した。

\section{对象と方法}

.実験は全てWistar 采雄性ラット体重約 $200 \mathrm{~g}$ を用い て施行した。

Higgins \& Anderson の手技に従い,5), ラットの肝約 2/3の部分切除啳, ガラクトース負荷試験を経日的に 7 日間施行し，残存肝重量を測定した。ガラクトース負 荷試験の検查方法および血中ガラクトース值の測定方 法は既報の如くとし6)，実験にはラットをそれぞれ 4 匹ずつを供した。

更に，部分肝切除後同時期に30\%ガラクトース $1 \mathrm{~m} l$ を股静脈より静注し、ガラクトース静注前, 静注 60 分 後，静注120分後に血糖值，血中乳酸値および血中イン スリン值を測定した。血糖は glucose oxidase 法, 乳 
酸は紫外部測定法のキットである Lactate-UV. method を用いて測定した。血中インスリンはRIA・2 抗体法により測定した(以下IRI と略す)。実験には血 糖值および血中乳酸值測定にそれぞれ 5 匹ずつ，血中 IRI 值測定に 4 7 匹ずつのラットを供した.

次に, 肝組織 glucose-6-phosphatase 活性を部分肝 切除後同時期に $30 \%$ ガラクトース静注前, 静注 60 分後, 静注120分後に測定した. glucose-6-phosphatase 活性 はAshmore ら゙の方法に準して測定し，15分間の phosphateの生成量で以って䣼素活性値とした。この 実験にはラットをそれぞれ5匹ずつ供した。

論文中の成績は平均値士標準偏差 $(M \pm S D) て ゙$ 示し， 統計学的解析は $\mathrm{t}$ 検定を施行した.

\section{成 䋶}

無処置ラットの肝重量は10.1 $00.7 \mathrm{~g}$ であり, 部分肝 切除 1 日後に $3.6 \pm 0.7 \mathrm{~g}$ と最小残存肝重量となり, 以 後徐々に増加して 7 日後には8.2 $00.3 \mathrm{~g}$ と無処置ラッ

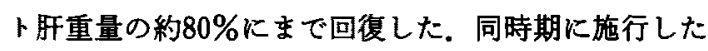
ガラクトース負荷試検の血中ガラクトース值半減期の 経日的変化は部分肝切除後の残存肝重量の経日的変化 とは異なった推移を示した．無処置ラットの血中ガラ クトース值半減期は $20.6 \pm 1.9$ 分であり, 部分肝切除 3 日後まで徐々に延長し，3 日後に71.2 28.0 分と最長半 減期となり,以後徐々に回復し 7 日後に $27.0 \pm 7.1$ 分を
示した（Fig. 1)。

無処置ラットの血糖值はガラクトース静注前に $155.7 \pm 6.7 \mathrm{mg} / \mathrm{d} l$ (以下単位は略す)，ガラクトース静

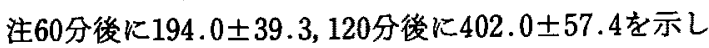
た. 部分肝切除後のガラクトース静注前血糖值は部分 肝切除の影響を受け，無処置ラットに比べると有意に 低値であった. 又,ガラクトース静注60分後括よび120 分後の血糖値の変動は同様の傾向を示し, 部分肝切除 3 日後玉で徐々に低下し，3 日後に132.2 234.3 (ガラ クトース静注60分後), $192.2 \pm 24.1$ (ガラク.トース静 注120分後) と最小血糖值を示し, 以後徐々に上昇し 7 日後に198.0土37.3 (ガラクトース静注60分後), $306.6 \pm 60.7$ (ガラクトース静注120分後)を示した (Fig. 2).

同時期に測定した無処置ラットの血中乳酸値はガラ クトース静注前に $13.13 \pm 1.84 \mathrm{mg} / \mathrm{d} l$ (以下単位は略 す), ガラクトース静注 60 分後に25.07士7.6, 120 分後 に28.09土7.19を示した. 部分肝切除後のガラクトース 静注前血中乳酸值は部分肝切除の影響を受け, 無処㯰 ラットに比べると有意飞高値であった。 又,ガラクトー ス静注 60 分後拉よび120分後の血中乳酸値の変動は同 様の傾向を示し、とくにガラクトース静注120分後の血 中乳酸値は部分肝切除 1 日後から 3 日後をで著明に高 値を示したが，部分肝切除 3 日後まで次第に上昇し，

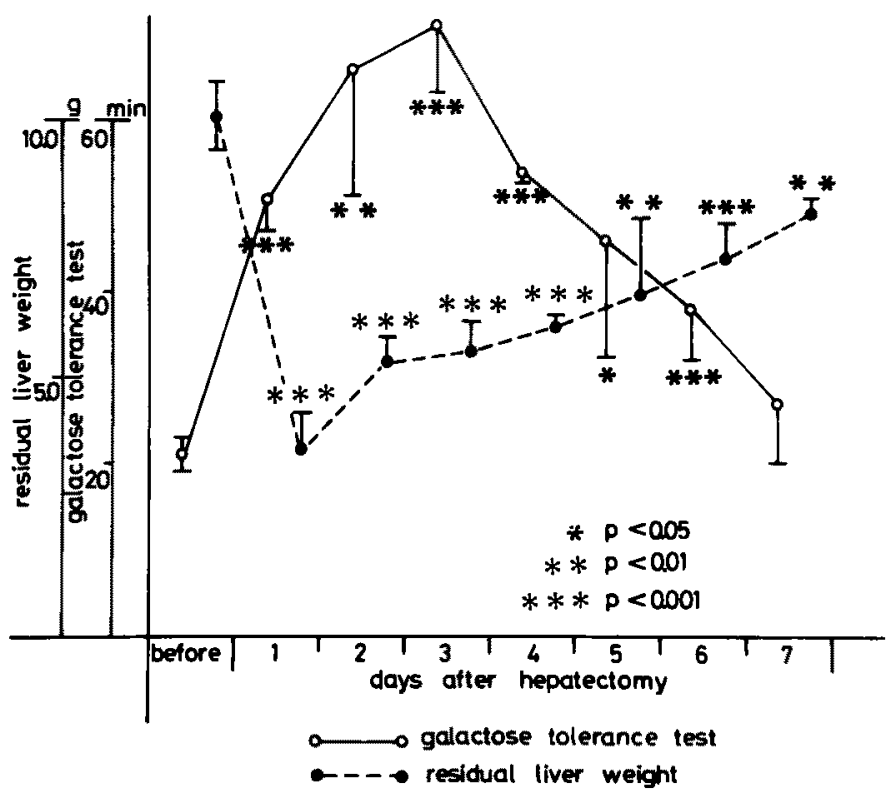

Fig. 1 Daily change of galactose tolerance test and residual liver weight after partial hepatectomy 


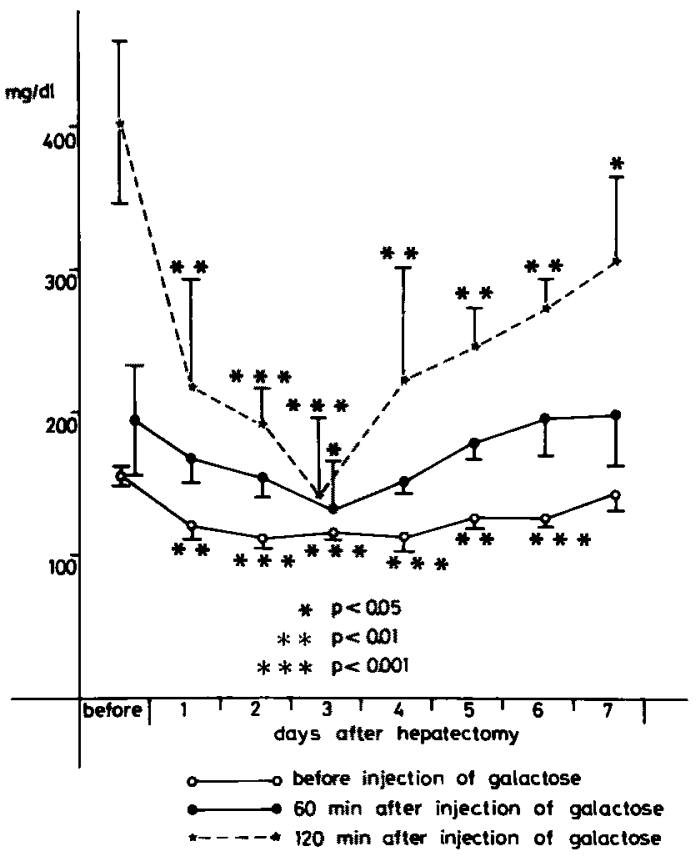

Fig. 2 Daily change of blood glucose concentra. tion after partial hepatectomy

3 日後に $64.89 \pm 26.57$ (ガラクトース静注 60 分後), $76.63 \pm 11.07$ (ガラクトース静注 120 分後) と最高血中 乳酸値を示し、以後徐々に低下して7 日後には26.75士 7.17 (ガラクトース静注60分後)，24.56士5.49（ガラ クトース静注120分後)を示した（Fig. 3).

一方，同時期に測定した血中 IRI 值は，部分肝切除 前後において明らかな有意差を認めなかった（無処置 ラットと部分肝切除 1 日後のラットにおいて，がラク


有意差を認めた). 無処置ラットの血中 IRI 值はガラク $\vdash$ ト静注前に $25.0 \pm 11.3 \mu \mathrm{U} / \mathrm{m} l$ (以下単位は略す),

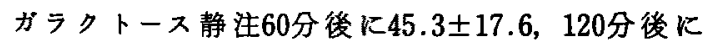
$33.8 \pm 11.7$ を示した。即ち，血中 IRI 值の変動は部分 旰切除前後の経日的变化で血糖値および血中乳酸値の 変動とは異なり,ガラクトース静注120分後よりは60分 後の血中乳酸值が高値を示した。更に, 部分肝切除啳 の血中 IRI 値の変動は，ガラクトース静注前，静注60 分後および120分後のいずれも同様の傾向を示し, 部分 肝切除 3 日後までは低值の傾向で，上くに部分肝切除 1 日後に最小血中 IRI 值である20.3土6.8(ガラクトー ス静注前), $24.3 \pm 9.6$ (ガラクトース静注60分後), $17.0 \pm 5.6$ (ガラクトース静注120分後)を示し, それ

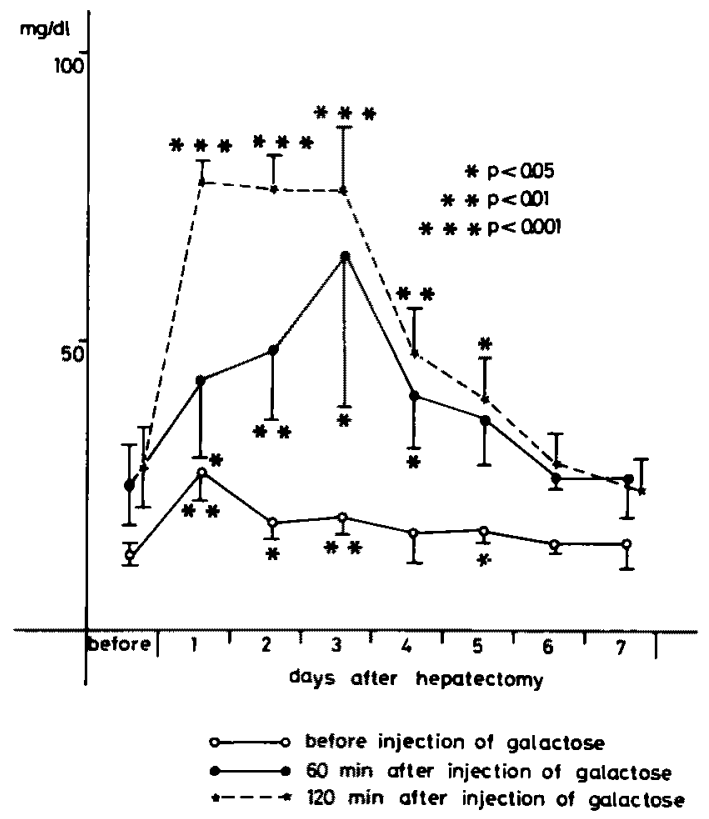

Fig. 3 Daily change of blood lactate concentration after partial hepatectomy

以後徐々に上昇し， 7 日後に $30.4 \pm 13.7$ (ガラクトー

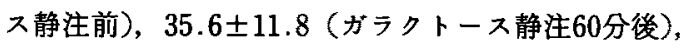
$34.6 \pm 16.4$ (ガラクトース静注 120 分後) を示した. こ の部分肝妡除後の血中 IRI 值のガラクトース静注前後 の変動は, Fig. 2の部分汗切除後の血糖値の変動と比 較対照すると再生肝のガラクトース代謝に影響をおよ ぼしていると考えるよりる血糖値の変動に応じた血中 インスリンの反応であることが示唆された (Fig. 4).

更に，同時期に測定した盰組織 glucose-6-phosphatase 活性値は, 部分肝切除後に括いてガラクトー ス静注前, 静注60分後および120分後のいずれとも同様 の傾向を示した．無処置ラットの glucose-6-phosphatase 活性值はガラクトース静注前に0.2293士 $0.0262 \mu \mathrm{M}$ phosphate product $/$ reaction $/ 15 \mathrm{~min}$ (以下 単位は略す),ガラクトース静注60分後に0.2378士 $0.0439,120$ 分後に0.3029士0.0459を示した。部分肝切 除後, glucose-6-phosphatase 活性値は次第に低下し, 部分肝切除 3 日後に0.1290士0.0144（ガラクトース静 注前), $0.1347 \pm 0.0126$ (ガラクトース静注60分後), $0.1802 \pm 0.0050$ (ガラクトース静注 120 分後）と最小 glucose-6-phosphatase 活性值を示し，それ以後徐々に 上昇し， 7 日後に $0.1680 \pm 0.0332$ (ガラクトース静注 前), $0.1837 \pm 0.0290$ (ガラクトース静注60分後), 
$4: 1094$

肝

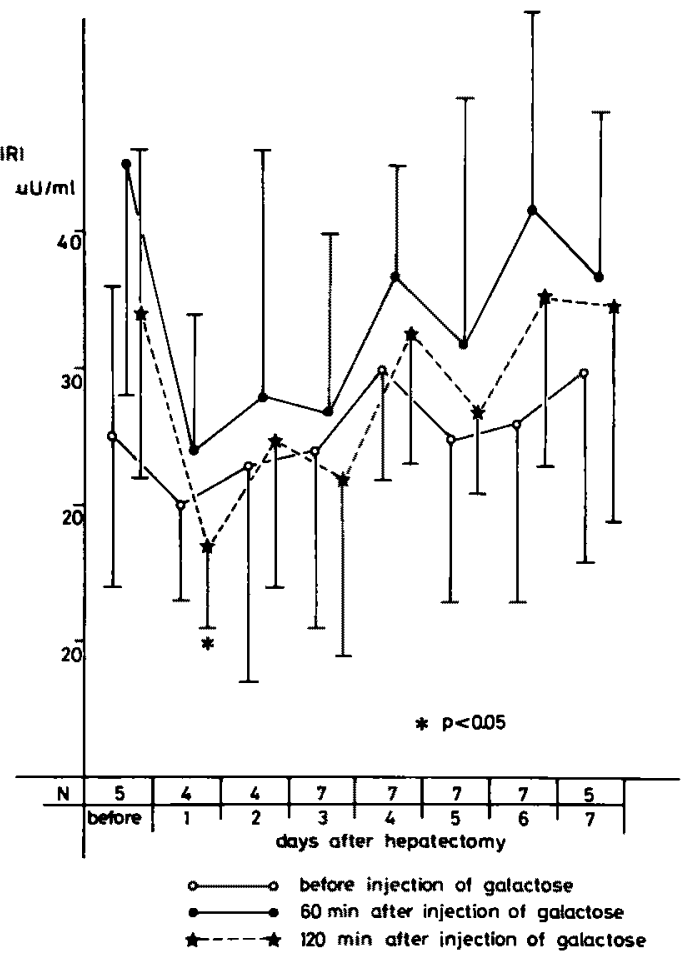

Fig. 4 Daily change of serum IRI concentration after partial hepatectomy

$0.2066 \pm 0.0201$ (ガラクトース静注120分後)を示した (Fig. 5).

\section{考 察}

現在，肝予備能唡查としては，ICG Rmax を主とし てグルカゴン負荷試験，ガラクトース負荷試験，ブド ウ糖負荷試験等の負荷試験が各施設で施行されてい る。しかしここれら負荷試験の成䋶間において臨床 的に解離症例が存在することはよく知られている事串 である1.

著者らは，ラットを用いた実験で，ガラクトース負 荷試験の成績が肝重量と平行しないことにより，肝重 量が必ずしす肝の functional reserve cell massを反 映するものではないことを指摘した 2 ,6).

著者らと同様の実験を施行しているYildirimら (は3)，部分肝切除 3 日後まで肝のガラクトース除去能 は低下するが，部分肝切除 6 時間後に肝のガラクトー ス除去能が一時的に改善することを認め，再生訮に特 異なガラクトース代謝状態があることを示唆し，更に， ガラクトース代謝の律速酵素である galactokinase ${ }^{8)}$ とガラクトース代謝系のその他の醭素を検討すること
25巻 9 号（1984）

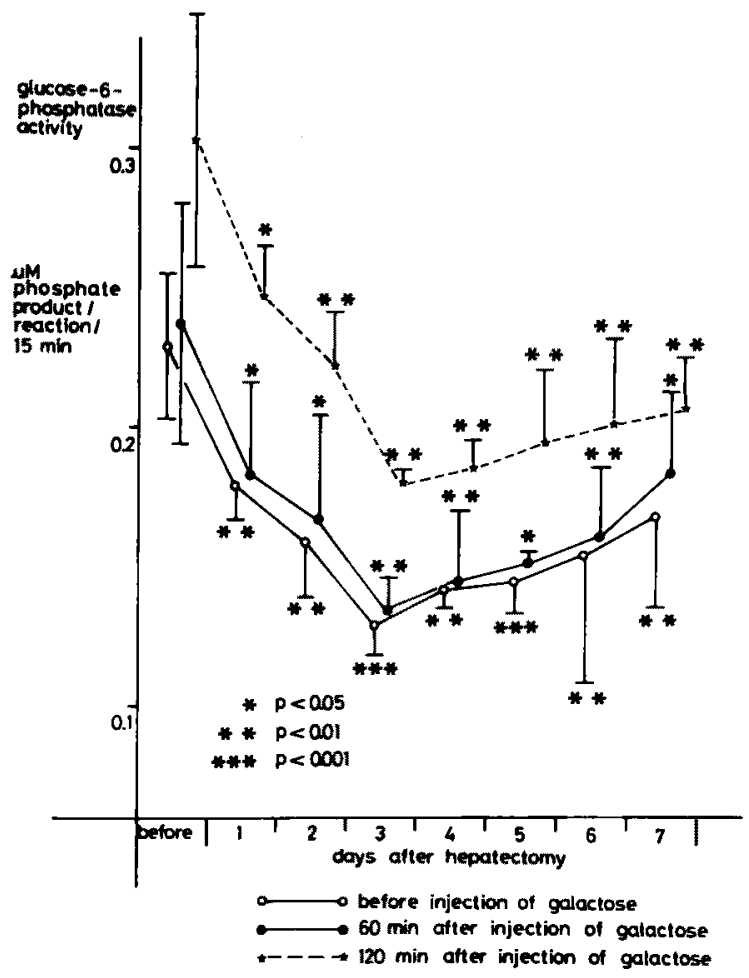

Fig. 5 Daily change of glucose-6-phosphatase activity in liver tissue after partial hepatectomy

が，再生肝のガラクトース除去能の一時的改善といら 現象に解決を与えてくれるのではないかと推論してい る.

著者らもガラクトースがエネルギー代謝といら生理 的に重要な代謝に関与する物質であることを考虑し， 再生肝といらエネルギーを高率に必要とする状態に拧 いては，ガラクトース代謝も特異的になることを推測 し，このことか，部分肝切除後の残存肝重量とガラク トース負荷試験の成績とが解離する原因の一つになっ ている可能性を指摘しだ9.

ガラクトースは，生体内では数\%が腎で排泄される が10)，主として肝で代謝され肝紐胞内に取り込まれた ガラクトースは galactokinase, galactose-1-phosphate uridyl transferaseの作用によりUDPgalactose となる。更に, UDP-galactose はUDP. glucose となり, glycogenesis の径路によって容易に glycogen K合成される代謝系によりgalactose は土 ネルギー源として生体内に供給されると考えられてい る. 本論文では, このガラクトースの代謝系のなかで， glycogen が分解されて生じる glucose, glucose-6- 
phosphate から TCA サイクルの径路へ移行する際に 生じる中間代謝産物の乳酸および glucose-6-phosphateからglucoseへ転換される時作用する glucose-6-phosphatase について再生肝のガラクトー ス代謝と関連つけて検討し，又，ガラクトース代謝に 影響を拉よぼすと考兄られているインスリン4ににい ても同様に検討した.

部分肝切除後の血糖值のガラクトース静注後の経日 的変化はガラクトース負荷試験の成績の経日的変化上 相互関係を示した. 即ち, 部分肝切除後のガラクトー 又負荷試験の成績は, 部分肝切除 3 日後までは肝のガ ラクトース取り込み量が次第に减少し，その後徐々に 増加するといら経日的变化を示したが，血糖值の経日 的変化はこの肝のガラクトース取り込み量を反映する ものであった．肝のガラクトース取り込み量が次第に 减少する部分肝切除 3 日後までは glycogen から分解 されて生じる血糖值も次第に低下し，それ以後徐々に 増加する肝のガラクトース取り込み量に平行して血糖 值も徐々に上昇した。

glycogenから分解されて生じる glucose-6-phosphate glucose になる径路とピルビン酸, 乳酸を経てTCA サ イクルに入る径路との 2 つ代謝径路に分かれると考

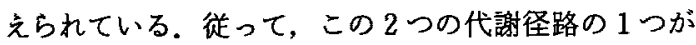
障害されている場合は，他方の代謝径路へ進む割合が 高くなり，その代謝径路の中間代謝産物の血中濃度は 上笔してくることが考えられる，以上の意味から， glucose-6-phosphatase はガラクトースの代謝系のな かで glycogen が分解される以下の代謝径路を考える 上で重要な醉素であるといえる。しかし，ガラクトー ス代謝に関与する䣼素のなかで, 最す重要な酵素はガ ラクトース代謝の律速酳素と考えられている galactokinaseであり ${ }^{8)}$, 本論文では, この醳素に関しては検討 しなかったが，今後，再生肝のガラクトース代謝を考 える上で検討されるべき醇素と考光ている。

部分肝切除後の血中乳酸値の変動に関しては, 部分 所切除の影響を無視できないが，血糖値および glucose-6-phosphatase 活性值の变動と相反する相互 関係を示した。即ち，部分肝切除後 glucose-6-phosphatase 活性值が次第に低下するのに反して血中乳酸 值は上昇 L, 部分肝切除 3 日後以後 glucose-6-phosphatase 活性值が徐々に上昇するのに反して血中乳酸 值は徐々に低下した。従って, glucose-6-phosphate 以 下の再生肝のガラクトース代謝系のなかで glucose-6- phosphatase 活性值の変動は，部分肝切除 3 日後まで は，より乳酸に転換される径路に，部分肝切除 3 日挠 以後は，より glucose 记転換される径路に一とガラク トース代謝系を方向づけていることが示唆された。

ガラクトース代謝に影響を扣よばしていると考京ら れているインスリンは4)，再生肝においては血糖値の 变動に応じた反応を示した，更に，血中ガラクトース 值の変動に対してはインスリンは反応しないことが既 に報告があるが垃，著者らの実験結果からもがラク トースから生じた glucose が血糖値の変動となること により血中インスリン值に変動が生じることが示唆さ れ，再生肝に怙いては肝のガラクトース取り込みには インスリンは直接に影響を扣よばしていないことが示 唆された。

\section{結 語}

再生肝のガラクトース代謝を研究するためにラット を用いて部分肝切除後，血糖，血中乳酸，肝組溗 glucose-6-phosphatase 活性扰よび血中インスリンを 経日的に測定した結果，肝組織 glucose-6-phosphatase 活性値の変動が再生肝のガラクトース代謝に影響を括 上ぼしている可能性が指摘され，又，インスリンは再 生肝のガラクトース取り远みに直接には関与していな いことが示唆された。

\section{文献}

1）中西钽夫，川本広夫，吉川正哉任か：各種肝子㑤能 查の比較梌討。広鳥医学 35：1449-1454, 1982

2）竹崎英一，坪倉篤雄, 中西敏夫はか：ガラクトース 負荷試験の実験的検討。医学のあゆみ 125 ： 1003-1005, 1983

3) Yildilim SI, Poulsen HE: Quantitative liver functions after $70 \%$ hepatectomy. Europ J Clin Invest $11: 469-472,1982$

4) Elia M, Oppenheim WL, Smith $R$, et al: Changes in blood glucose and plasma insulin after intravenous galactose in human injury. Clin Sci 57 : 249-256, 1979

5) Higgins GM, Anderson RM : Experimental pathology of the liver. Arch Pathol 12: 421 $-429,1974$

6）竹崎英一, 中西敏夫, 川本広夫ほか：肝予備能検査 法としてのがラクトース負荷試験の実験的検討 (ICGRmax との比較検討)。肝臓 $24: 1235-$ 1241,1983

7) Ashmore J, Hastings AB, Nesbett FB: The effect of diabetes and fasting on liver glucose-6. 
phosphatase. Proc Nat Acad Sci 40 : 673-678, 1954

8) Keiding S, Vinterby Aa: Oroate decrease the inhibitory effect of ethanol on the galactose elimination in the perfused rat liver. Biochem $\mathrm{J}$ $160: 712-720,1976$

9）竹崎英一，坪倉篤雄, 中西敏夫ほか：負荷試験に拉
ける肝予備能力の解析. 臨床病理 $32: 577-583$, 1984

10) Keiding $S$ : Galactose elimination capacity in the rat. Scand J Clin Invest $31: 319-325,1973$

11) Samols E, Dormandy TL: Insulin response to fructose and galactose. Lancet $1: 478-479,1963$

\title{
Experimental study on galactose tolerance test as a test for functional reserve cell mass of the liver - galactose metabolism in regenerating rat liver-
}

\author{
Eiichi Takezaki*, Toshio Nakanishi, Yasuyuki Watanabe, Hiroo Kawamoto, \\ Masaya KikKawa, Toshijiro MatsuURa, Hiromu TaKeno, \\ Hiroiku KAWAKAMI and Goro KAJIYAMA**
}

In previous experimental study, we found the dissociation between residual liver weight and estimation of galactose tolerance test as a test for functional reserve cell mass of the liver after partial hepatectomy. It was indicated that liver weight never paralleled with changes of functional reserve cell mass of the liver.

On the other hand, it might be possible that there was an unknown galactose metabolism in regenerating rat liver.

In this paper, we studied the effect of regenerating rat liver on blood glucose, lactate, insulin and glucose-6-phosphatase in liver tissue. Conclusively, we found that the effect of glucose-6phosphatase activity was significant on galactose metabolism and blood insulin, known as a regulator of galactose metabolism, was no effect on galactose metabolism in regenerating rat liver.

* Department of Clinical Pathology, School of Medicine, Hiroshima University (Hiroshima)

** The 1st Department of Internal Medicine, School of Medicine, Hiroshima University (Hiroshima) 